\title{
PRE-TRIAL DETENTION OF CHILDREN: EUROPEAN STANDARDS AND CROATIAN LAW*
}

\author{
Marija Pleić, PhD, Assistant Professor \\ University of Split, Faculty of Law \\ Domovinskog rata 8, Split, Croatia \\ marija.pleic@pravst.hr
}

\author{
Ivana Radić, PhD, Postdoctoral Researcher \\ University of Split, Faculty of Law \\ Domovinskog rata 8, Split, Croatia \\ iradic@pravst.hr
}

\begin{abstract}
This paper deals with the issue of pre-trial detention of children in criminal proceedings from the aspect of European standards established under the competence of the European Court of Human Rights and the EU law, as well as from the aspect of Croatian criminal procedure law. Authors will first provide a short overview of international documents pertaining to the issue of deprivation of liberty of children. Furthermore, they will analyse the relevant case law of the European Court of Human Rights, especially the recent one. In several cases, ECHR established a violation of Art. 5 because pre-trial detention had not been used as a measure of last resort i.e., domestic courts did not take into account the applicants' young age when deciding on pretrial detention. Hence, special attention in the paper will be given to the provisions of Directive 2016/800/EU_on procedural safeguards for children who are suspects or accused persons in criminal proceedings. Articles 10 to 12 of the Directive emphasise the ultima ratio nature of detention, the need for a periodic judicial review of the decision, the availability of alternative decisions and specific treatment regarding the separation of children from adults, health care, education and family life. The adequacy of the measure of pre-trial detention for children has recently been discussed in the Croatian judicial practice regarding the case of a fourteen-year old child accused of aggravated murder. The issue of national law on pre-trial detention is especially relevant in the context of the need to transpose Directive 2016/800. Consequently, the authors will critically examine the Croatian legislation and practice and their compliance with the European standards on pre-trial detention.
\end{abstract}

Keywords: deprivation of liberty, Directive 2016/800/EU, European Court of Human Rights, pre-trial detention of children

This paper is a product of work that has been supported by the Croatian Science Foundation under the project 8282 'Croatian Judicial Cooperation in Criminal Matters in the EU and the Region: Heritage of the Past and Challenges of the Future' (CoCoCrim) 


\section{INTRODUCTION}

\subsection{Definition and scope}

Deprivation of liberty, as the most coercive measure in the criminal proceedings, should be used as a last resort, and this principle is especially emphasised in relation to children who are in a particularly vulnerable position regarding their physical and mental condition upon detention. Inadequate detention conditions can have detrimental effects on children, contrary to the purpose of the criminal proceedings which should be focussed on the upbringing, needs and best interests of a child. As the research indicates, even short periods of detention can undermine a child's psychological and physical well-being and compromise cognitive development. ${ }^{1}$

Pre-trial detention, in the context of this paper, should be defined as a procedural measure of deprivation of liberty of the suspect or the accused, determined by a court before or during the criminal proceedings under prescribed legal conditions consisting of temporary detention for the purpose of securing a particular scope prescribed by criminal procedural law. ${ }^{2}$ The analysis focusses on the measure of pre-trial detention imposed on children defined in accordance with the United Nations Convention on Rights of a Child (UNCRC) ${ }^{3}$ as persons below the age of eighteen years, which is also the wording of Directive (EU) 2016/800 on procedural safeguards for children who are suspects or accused persons in criminal proceedings. ${ }^{4}$ Other child-related international documents and the European Court of Human Rights (ECHR) use the term "minors" or "juvenile". The Croatian Juvenile Courts Act (JCA) uses the term minor for a person whose age, at the time of perpetration, was between fourteen and eighteen, and it distinguishes junior minors (14-16 years old) and senior minors (16-18 years old)..$^{5}$

In this paper, the authors will focus on international, especially the European standards, on the use of pre-trial detention on children in view of the abundant ECHR case law and the new EU legislation regarding this issue, and the manner in which these standards are implemented in the Croatian law, i.e. to what extent the Croatian legislation and practice are harmonised with these standards.

1 Fair Trials: Advancing the Defence Rights of Children Manual for Practitioners, October 2018, p. 32, [https://www.fairtrials.org/publication/advancing-defence-rights-children] Accessed 06.05.2019

2 Krapac, D. et al., Kazneno procesno pravo, Prva knjiga: Institucije, Zagreb, 2014, p. 381

3 UN Convention on Rights of a Child, General Assembly resolution 44/25 of 20 November 1989

4 Directive (EU) 2016/800 on procedural safeguards for children who are suspects or accused persons in criminal proceedings [2016] OJ L 132

5 Article 2, Juvenile Courts Act, Official Gazette, 84/11, 143/12, 148/13, 56/15 


\subsection{Data on the use of pre-trial detention on children}

Even though the official international statistics do not present the number of children in detention before and during the trial in Europe and throughout the world, the issue of overuse of pre-trial detention can be detected. It is estimated that in 2011, a total of 3386 children were held in pre-trial detention in only $7 \mathrm{EU}$ Member States. ${ }^{6}$ The experts state that a routine use of pre-trial detention is considered as one of the most pressing issues in the present juvenile justice system and that the real problem lies with the practices and not the norms. ${ }^{7}$ Some research indicates a strong correlation between the pre-trial detention and the imposed custodial sentence to children, i.e. the pre-trial detainees are more likely to get a custodial sentence after conviction. ${ }^{8}$

In all EU Member States (EUMS), the pre-trial detention is applicable to children who have reached the minimum age of criminal responsibility which is mostly between the age of 13 and 15, with the exception of 5 jurisdictions which apply a lower age limit.' According to the available data in most EUMS, the age limit for the pre-trial detention overlaps with the age limit prescribed for the custodial sanctions and measures, ${ }^{10}$ but few countries, including the Republic of Croatia, ${ }^{11}$ have a higher age limit for the implementation of custodial sanctions with respect to the pre-trial detention, i.e., in these countries the children liable to pre-trial detention cannot be subjected to custodial measures. This legal solution can lead to a paradox where a more severe measure may be imposed on the accused child during the trial while he/she is presumed innocent than after the trial.

6 Duroy, S.; Foussard, C.; Vanhove, A., Pre-trial detention of children in the EU, Analysis of legislations and practices in EU28, p. 3, [http://www.ijjo.org/sites/default/files/mipredet_ijjo2015_updated07122016. pdf] Accessed 03.05.2019

7 Volz, A., Stop the violence! The overuse of pre-trial detention, or the need to reform juvenile justice systems, Review of Evidence, Defence for Children International, Geneva, July 2010, p. 9-10,

[https://defenceforchildren.org/wp-content/uploads/2010/04/PretrialDetentionReport-dci.pdf] Accessed 03.05.2019

8 Research was conducted in the Netherlands. Van den Brink, Y., Pre-Trial Detention of Children, Children's Rights, Welfarism and Control, World Congress on Justice for Children, 29 May 2018, p. 9, [https://j4c2018.org/wp-content/uploads/2018/04/YANNICK-VAN-DEN-BRINK-PRESENTATION-PRETRIAL-DETENTION-29.05.18-ROOM-III.pdf] Accessed 03.05.2019

9 MIPREDET: Analysis of procedures and conditions of minors' pre-trial detention, JUST/2014/ JACC/AG/PROC/6600, Final report, p. 12,

[https://www.oijj.org/sites/default/files/mipredet._final_publication.pdf] Accessed 04.05.2019

10 European Union Agency for Fundamental Rights: Mapping minimum age requirements with respect to the rights of the child in the EU, 2017, [https://fra.europa.eu/en/publications-and-resources/dataand-maps/minag?mdq1=theme\&mdq2=3509] Accessed 04.05.2019

${ }^{A}$ ccording to this report Republic of Croatia is misplaced in the category of countries with categorical value $15-16$ for pre-trial detention instead in category of $13-14$ years

11 Belgium, Hungary, Slovenia, ibid. 
The Committee on the Rights of the Child, currently revising its General Comment No. 10 (2007) on children's rights in the juvenile justice system, proposed 16 years as the age limit for the use of the deprivation of liberty, either at the pretrial or post-trial stage. ${ }^{12}$ This proposal, according to some commentators, does not contribute to public safety and is incompatible with the harsh realities juvenile justice practitioners face in daily practice. ${ }^{13}$

Data on the use of pre-trial detention of children in the Republic of Croatia imply a relatively small number of children in pre-trial detention. ${ }^{14}$ In the last five years, this number has varied from 57 in 2013, 49 in 2014, 30 in 2015, 33 in 2016 and 45 children in 2017. However, an increase in the number of pre-trial detainees in 2017 is rather indicative, especially in relation to the decreasing number of accused minors. ${ }^{15}$

\section{INTERNATIONAL DOCUMENTS ON PRE-TRIAL DETENTION OF CHILDREN}

International community has developed a set of specific standards on the deprivation of liberty of children, and Article 37 of UNCRS, the most important international instrument for the protection of the children`s rights, prescribes the relevant binding rules. UNCRC together with the soft law documents which are more specifically oriented towards the juvenile justice system and deprivation of liberty, Beijing Rules ${ }^{16}$ and Havana Rules, ${ }^{17}$ "serve as a comprehensive, internationally accepted framework to be incorporated by states with a view to counter-

12 Paragraph 101, Committee on the Rights of the Child, Draft General Comment No. 24 (201x), replacing General Comment 10 (2007) on Children's rights in juvenile justice,

[https://www.ohchr.org/EN/HRBodies/CRC/Pages/DraftGC10.aspx] Accessed 04.05.2019

13 Comments on Draft General Comment No. 24 (201x), replacing General Comment 10 (2007) on Children's rights in juvenile justice, Department of Child Law, Leiden Law School, Leiden University, The Netherlands Leiden, 7 January 2019,

[https://www.universiteitleiden.nl/binaries/content/assets/rechtsgeleerdheid/instituut-voor-privaatrecht/jeugdrecht/leiden-university-comments-draft-gc-no.-24-final.pdf] Accessed 04.05.2019

14 Data obtained from Administration for Prison System and Probation of Ministry of Justice, Republic of Croatia.

15 In 2017 a total of 380 minors where accused for criminal offences, in 2016 422, in 2015 492, in 2014 626 and in 2013 637. Data from Statistical Yearbooks of the Republic of Croatia, Croatian Bureau of Statistics, available at [https://www.dzs.hr/default.htm] Accessed 06.05.2019

16 United Nations Standard Minimum Rules for the Administration of Juvenile Justice, Adopted by General Assembly resolution 40/33 of 29 November 1985

17 United Nations Rules for the Protection of Juveniles Deprived of their Liberty, Adopted by General Assembly resolution 45/113 of 14 December 1990 
acting the detrimental effects of detention." ${ }^{18}$ In the European context, the instruments under the Council of Europe should be added to this list and furthermore analysed, especially the European Rules for juvenile offenders ${ }^{19}$ and Guidelines on child-friendly justice. ${ }^{20}$

Considering the importance of the standards established by the ECHR case law, and the development of new binding standards under the European Union law, these will be further analysed in Chapters 3 and 4 .

\subsection{Basic principles}

The basic principle provided in Article 37(b) of UNCRC in relation to detention is the principle of legality which encompasses lawfulness and non-arbitrariness. ${ }^{21}$ Furthermore, in terms of children in pre-trial detention, the presumption of innocence should be the leading principle for the treatment of untried detainees. ${ }^{22}$

All international instruments on children`s rights highlight the ultima ratio nature of detention: pre-trial detention can be used only as a measure of last resort and for the shortest appropriate period of time, i.e. with utmost restraint and only after careful consideration. ${ }^{23}$ The principle of last resort requires that alternative options to detention be considered, ${ }^{24}$ hence special efforts must be undertaken to avoid pre-trial detention. ${ }^{25}$

This principle requires not only that alternative options should be considered but also that an 'appropriate' time frame is considered. ${ }^{26}$ In that sense, the internation-

18 Manco, E., Detention of the Child in the Light of International Law-A Commentary on Article 37 of the United Nation Convention on the Rights of the Child, Amsterdam Law Forum, Vol. 7, No. 1, 2015, p. 58

19 Recommendation CM/Rec (2008) 11 of the Committee of Ministers to member states on the European rules for juvenile offenders subject to sanctions or measures adopted by the Committee of Ministers on 5 November 2008

20 Guidelines of the Committee of Ministers of the Council of Europe on child-friendly justice adopted by the Committee of Ministers of the Council of Europe on 17 November 2010. We should also mention Recommendation of the Committee of Ministers to Member States of the Council of Europe on social reactions to juvenile delinquency (no. R (87)20), Recommendation Rec (2003) 20 of the Committee of Ministers of the Council of Europe concerning new ways of dealing with juvenile delinquency and the role of juvenile justice

21 Cf. Liefaard, T., Deprivation of Liberty of Children in: Kilkelly, U.; Liefaard, T. (eds.), International Human Rights of Children, Springer, 2019, p. 333

22 Havana Rules, 17; European Rules, 108

23 Liefaard, op. cit., note 23, p. 329

24 Havana Rules, 13.2.; Beijing Rules, 17; Recommendation Rec (2003) 20, 17

25 European Rules, 10

26 Manco, op. cit., note 20, p. 63 
al standards require the use of pre-trial detention only for the shortest appropriate $^{27}$ or shortest possible time. Liefaard emphasises that appropriateness should be understood in the light of the impact of deprivation of liberty on children, including the level of security. In particular, with regard to the use of pre-trial detention, this is supported by the Beijing Rules, Havana Rules, European Rules and ECHR case law which prescribe the shortest possible time. ${ }^{28}$ In considering whether to prevent further offending by remanding a child in custody, the courts should undertake a full risk assessment based on comprehensive and reliable information on the young person's personality and social circumstances. ${ }^{29}$

\subsection{Procedural rights}

International instruments set up habeas corpus rights for children deprived of liberty: right to a prompt access to legal and other appropriate assistance, right to challenge the legality of the deprivation of liberty before a court or other competent, independent and impartial authority, and to a prompt decision on any such action. ${ }^{30}$ According to the Committee on the Rights of Children (CRC Committee), every child arrested and deprived of his/her liberty should be brought before a competent authority to examine the legality of the deprivation of liberty or its continuation within 24 hours and the legality of a pre-trial detention has to be reviewed regularly, preferably every two weeks. ${ }^{31}$ Furthermore, the competent authority should make a final decision on the charges no later than six months after they have been presented. Right to a prompt decision implies that a decision must be rendered within or no later than two weeks after the challenge has been made. Recommendation Rec (2003) 20 provides that children should not be remanded in custody for longer than six months before the commencement of the trial. This period can only be extended if a judge who is not involved in the investigation of the case is convinced that any delays in proceedings are completely justified due to exceptional circumstances.

UNCRC, Guidelines of CoE on child friendly justice, Directive 2016/800

Liefaard, op. cit., note 23, p. 332

Recommendation Rec (2003) 20, 18

Article 37 (d) UNCRC

Committee on The Rights of the Child, General Comment No. 10 (2007) Children's rights in juvenile justice, CRC/C/GC/10 25 April 2007, paragraph 83. [https://www.refworld.org/docid/4670fca12. html] Accessed 06.05.2019. New Draft of General Comments proposes review of legality on a weekly basis. Draft General Comment, op. cit. note13, paragraph 102 


\subsection{Treatment of detainees}

The fundamental principle regarding the treatment of child detainees is the requirement of humane treatment with respect for the inherent human dignity in a manner which is adequate to a child's age. ${ }^{32}$ The first obligation that arises from this principle is to separate children in detention from adults, unless it is considered in the child's best interest not to do so. Unlike the Beijing Rules, ${ }^{33}$ the CRC Committee explicitly states that a child deprived of liberty should not be placed in a prison for adults and that states parties should establish separate facilities for children deprived of their liberty, which should include, according to the new Draft of General Comment, appropriately trained personnel and operate according to child-friendly policies and practices. ${ }^{34}$ Havana Rules further require that untried detainees should be separated from convicted juveniles. ${ }^{35}$ European Rules also state that juveniles should not be detained in institutions for adults but rather in institutions specially designed for them. According to the Guidelines on child-friendly justice when children are detained with adults, this should be for exceptional reasons and based solely on the best interests of the child. In all circumstances, children should be detained in premises suited to their needs.

The second aspect of the right of human treatment relates to the right of a child to maintain contact with his/her family through correspondence and visits, except in exceptional circumstances. ${ }^{36}$ While in custody, the juveniles should receive care, protection and all necessary individual social, educational, vocational, psychological, medical and physical assistance that they may require in view of their age, sex and personality. ${ }^{37}$ According to Havana Rules, the conditions under which an untried juvenile is detained should take into account the requirements of the presumption of innocence, the duration of the detention and the legal status and circumstances of the juvenile. ${ }^{38}$ Among other requirements, the CRC Committee emphasises that every child has the right to be examined by a physician or a health practitioner upon admission to the detention/correctional facility and receive adequate medical care. ${ }^{39}$

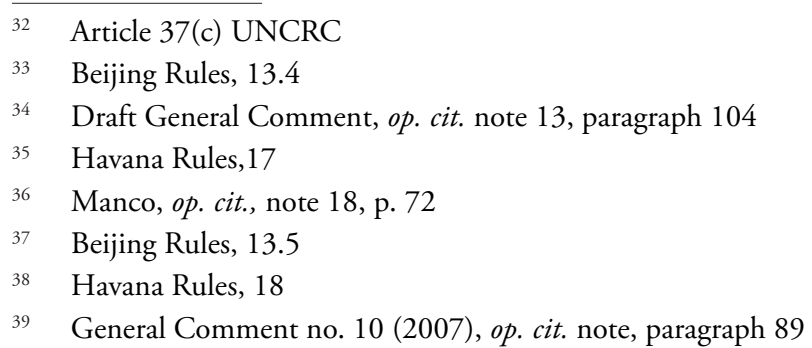




\section{ECHR STANDARDS ON PRE-TRIAL DETENTION OF CHILDREN}

\subsection{Pre-trial detention of children under the European Convention on Human Rights (the Convention) ${ }^{40}$}

The right to personal liberty is guaranteed by Article 5 para 1 . of the Convention which sets out an exhaustive list of legitimate grounds for detention. ${ }^{41}$ Detention for purposes of criminal proceedings is regulated by sub-paragraph c). It is necessary to delimit the scope of application of sub-paragraph d) which allows detention of a minor by lawful order for the purpose of educational supervision or their lawful detention for the purpose of bringing them before the competent legal authority in relation to sub-paragraph c). The deprivation of liberty under subparagraph d) cannot be justified in cases involving minors charged with the offence, but such deprivation of liberty should have its basis in sub-paragraph c.). ${ }^{42}$ However, the detention of a minor accused of a crime during the preparation of a psychiatric report necessary for deciding on his/her mental conditions has been considered to fall under sub-paragraph d) as detention for the purpose of bringing a minor before the competent authority. ${ }^{43}$

Paragraphs 2 and 4 of Article 5 set out specific rights guaranteed to all persons deprived of their liberty (right to be informed of the reasons for the arrest and the right to habeas corpus proceedings ${ }^{44}$ ), while paragraph 3 consists of two specific safeguards which only apply to detention for the purposes of criminal proceedings: right to be brought before the judge and right to be released within reasonable time. ${ }^{45}$

\subsection{ECHR case law on pre-trial detention of children}

The European Court of Human Rights developed a specific case law on pre-trial detention of children. This case law mostly refers to Article 5 (lawfulness and

40 Convention for the Protection of Human Rights and Fundamental Freedoms, Council of Europe, 1950

41 Trechsel, S., Human Rights in Criminal Proceedings, Oxford, 2006, p. 503

42 see Graovac, G., Zaštita prava na osobnu slobodu u praksi Ustavnog suda Republike Hrvatske, doktorski rad, Zagreb, 2017, pp. 185. - 186

43 X. v. Switzerland, no. 8500/79, Commission decision of 14 December 1979, Guide on Article 5 of the Convention - Right to liberty and security, Council of Europe/European Court of Human Rights, 2019, pp. 23

[https://www.echr.coe.int/documents/guide_art_5_eng.pdf] Accessed 06.05.2019

44 That is right to take proceedings to review the lawfulness of detention

45 See Trechsel, op. cit. note 41, pp. 408, 503 
length of pre-trial detention, habeas corpus proceedings), however, when conditions of the placement and treatment of detainees are concerned, it can raise the issue of inhumane and degrading treatment under Article 3 of the Convention.

Supporting the requirements of the international documents, ECHR believes that pre-trial detention of minors should be used only as a measure of last resort for the shortest possible period, ${ }^{46}$ and, where detention is strictly necessary, minors should be kept apart from adults. ${ }^{47}$

\subsubsection{Article 5 S 1}

According to ECHR standards, pre-trial detention is unlawful if it is not authorised by a judicial decision or if the domestic courts did not provide enough grounds for detention. This was the case in Kuptsov and Kuptsova v. Russia where ECHR found the period of almost six months of pre-trial detention for a 15-yearold accused of several counts of armed robbery unlawful due to the fact that there was no judicial decision authorising detention, and afterwards, when the court order was delivered, it did not provide any grounds for maintaining the custodial measure or fixing the time-limit for extended detention. ${ }^{48}$ In Grabowski v. Poland, ECHR found that the Polish practice of detaining juveniles, subject to correctional proceedings without a judicial decision authorising the continued detention, is contrary to the principle of legal certainty. ${ }^{49}$

The Court deems necessary that domestic courts should provide detailed reasons for the pre-trial detention and consider alternative measures before ordering the most coercive measure. Hence, in Korneykova v. Russia the Court concluded that the domestic authorities failed to advance comprehensive reasoning for imposing a custodial measure on the 14-year-old applicant. ${ }^{50}$ In assessing the lawfulness of the pre-trial detention, the health condition of a minor must be taken into account, which was not the case in Korneykova where the applicant suffering from tuberculosis and psychiatric disturbances was placed in a standard pre-trial detention facility for adults without assessing likelihood of damage to the applicant's

\footnotetext{
46 Korneykova v. Ukraine (2012), app. no. 39884/05,\$43-44, Selçukv. Turkey (2006), app. no. 21768/02, $\$ \$ 35-36$, Nart v. Turkey (2008), app. no. 20817/04, $\$ \$ 31$ and 33

$47 \quad$ Nart v. Turkey (2008), $\$ 31$

48 Kuptsov and Kuptsova v. Russia (2011), app. no. 6110/03, $\$ 82$

49 Grabowski v. Poland (2015), app. no. 57722/12, \$50. Applicant who was minor was arrested on suspicion of committing a number of armed robberies continued to be detained in the shelter for juveniles without any specific court order for the period of 5 months and 2 days

50 Korneykova v. Ukraine (2012), $\$ 48$
} 
health. ${ }^{51}$ In the recent judgement Agit Demir v. Turkey, the Court found that the placement in detention of a 13-year-old minor charged for participating in a demonstration could not be regarded as lawful as the reasons given by the magistrate in the pre-trial detention order did not suggest that the alternative measures, although provided by the law, had been considered first. ${ }^{52}$

In several cases, ECHR established a violation of Article $5 \$ 1$ due to the fact that the child's placement in detention was not justified on valid grounds covered by Article $5 \$ 1$, i.e., it could not fall under the scope of "educational supervision" as in the key case Blokhin v. Russia in relation to the 12-year-old applicant who, under the age of criminal liability, committed some criminal offences and was placed in temporary detention centre for young offenders in order to "correct his behaviour". ${ }^{33}$ Likewise, in Ichin and Others v. Ukraine, the Court reached the same conclusion regarding two minors who stole some food and kitchen appliances from a school canteen and were placed in a juvenile holding facility for 30 days. ${ }^{54}$

\subsubsection{Article $5 \$ 3$}

As the Court emphasises in its case law, Art $5 \$ 3$ should be read with Article 5 $\$ 1$ (c), which together form a comprehensive unit. It prescribes that the judicial authority should consider legal criteria relating to the merits of the detention and order provisional release if it is unreasonable, and secondly, it implies the right to release pending trial under reasonable circumstances. ${ }^{55}$

A significant factor in the balancing of relevant arguments pro and against release is the defendant's age. In a number of judgements, ECHR established a violation of Article $5 \$ 3$ due to the excessive periods of detention where the authorities did not take the young offender's age into consideration when deciding on the extension of pre-trial detention. That was the case in Selçukv. Turkey, where the applicant charged with robbery spent four months in pre-trial detention at the age of sixteen, and also in Nart v. Turkey in relation to the applicant who spent fortyeight days in detention at the age of seventeen on suspicion of armed robbery of a grocery shop and was kept in a prison with adults ${ }^{56}$ In Nart, ECHR emphasised that the question of whether or not a period of detention is reasonable had to be

\footnotetext{
$51 \quad$ Ibid., $\$ 47$

52 Agit Demir v. Turkey (2018), app. no. 36475/10, \$44-45

53 Blokhin v. Russia (2016), app. no. 47152/06, \$ $171-172$

54 Ichin and Others $v$. Ukraine (2010), app. nos. 28189/04 and 28192/04, \$ $39-40$

55 Harris, D.J.; O’Boyle, M.; Bates, E.P.; Buckley, M., Harris, O’Boyle \& Warbrick, Law of the European Convention on Human Rights, Oxford University Press, 2014, p. 338

$56 \quad$ Nart v. Turkey (2008), \$33
} 
determined on a case-specific basis, by considering whether or not there is a genuine requirement of public interest that outweighs the rule or respect of individual liberty. ${ }^{57}$ Furthermore, the Court established a violation of Article $5 \$ 3$ due to the excessive length of detention in Güveç v. Turkey, where the 15-year-old applicant charged with the offence of carrying out activities for the purpose of bringing about the secession of part of the national territory, was kept in pre-trial detention for a four and a half years. ${ }^{58}$ In Dinç and Çakir v. Turkey, the Court found that the reasons given in the decisions of the domestic courts were not sufficient or relevant to justify the applicants' continued detention which lasted in total one year and two months, whereas they did not provide any explanation as to the insufficiency of alternative measures to ensure the appearance of applicants at the trial who were taken into custody for having made and used Molotov cocktails at the age of $17 .{ }^{59}$

In Kuptsov and Kuptsova v. Russia, the Court noted that the detention of the first applicant which lasted slightly more than eleven months deprived him not only of his liberty, but also of an opportunity to attend school and pursue secondary education. ${ }^{60}$ The Court concluded that the domestic authorities bore responsibility for the four-month delay in the commencement of the trial taking into account the fact that a higher than usual degree of diligence in the conduct of the proceedings was required in view of the first applicant's age, and as a result he was denied a trial within a reasonable time in violation of Article $5 \$ 3 .{ }^{61}$ In the recent judgement Zherdev v. Ukraine, the Court concluded that although the reasoning for the severity of the charges against the applicant (at the age of 16 he was accused of murder and theft) and the risk of his absconding or interfering with the investigation had been given in the initial order for detention, it did not evolve with the passage of time. On several occasions, the domestic courts failed to provide any reasons whatsoever for their decisions for the extension of detention and, in view of the length of the applicant's detention (three years), this was sufficient to conclude that there has been a violation of Article $5 \$ 3 .{ }^{62}$

However, it should be emphasised that the young age and the prolonged detention itself are not sufficient to determine the breach of Article 5. Thus, in J.D. $v$. Denmark, where a 15-year-old applicant was charged with rape and homicide of an 85-year-old woman, the Court concluded that, having regard to the nature and

\footnotetext{
$57 \quad$ Ibid., $\$ 29$. See Fair Trials, op. cit. note 1, p. 34

58 Güveç v. Turkey (2009), $\$ 108-110$.

59 Dinç and Çakir v. Turkey (2013), app. no. 66066/09, \$ 60. - 66

60 Kuptsov and Kuptsova v. Russia (2011), $\$ 91$

${ }_{61} \quad$ Ibid., $\$ 94$

62 Zherdev v. Ukraine (2017), app. no. 34015/07, \$123-124
} 
severity of the crimes committed and to the vital significance of determining an appropriate sanction to be imposed on the applicant, the period of one year and four months, during which two forensic psychiatric examinations were carried out, cannot be considered excessive to such an extent that for that reason alone there was a breach of the invoked article. ${ }^{63}$ The other important factor for this conclusion was the fact that, for almost the entire period, the applicant was placed in a secure institution for young offenders meaning that Danish courts applied a less interfering measure than the ordinary pretrial detention. ${ }^{64}$

\subsubsection{Article $5 \mathfrak{S} 4$}

Regarding the procedural rights of minor detainees, the Court believes that the nature of the proceedings and the capabilities of an applicant determine whether the legal representation is required, in addition to the applicant's personal presence, by Article $5 \$ 4$ of the Convention in an oral hearing in the context of an adversarial procedure. ${ }^{65}$ The Court considers it to be essential for a lawyer to be present at a hearing where a juvenile is remanded in custody, otherwise a necessary safeguard would be denied. ${ }^{66}$ In Kuptsov and Kuptsova, the Court concluded that the appeal proceedings did not meet the "equality of arms" requirement since the counsel did not appear at the hearing where the first applicant was remanded in custody and neither the first applicant nor his lawyer were present at the appeal hearing, whereas the prosecutor attended and made oral submissions, so the first applicant was not afforded an adequate opportunity to participate in the examination of his appeal. ${ }^{67}$ Furthermore, the Court believed that the periods of thirty-three days to examine the first applicant's appeal against the detention order and twenty-five days to examine the appeal against the extension order cannot be considered compatible with the "speediness" requirement of Article $5 \$ 4 .^{68} \mathrm{In}$ Grabowski, the Court found that the decision of dismissing the child's application for release did not explain the legal basis for his continued detention in the shelter for juveniles and was therefore contrary to Art. $5 \$ 4 .{ }^{69}$

63 J.D. v. Danmark (2012), app. no. 34421/09, \$59

$64 \quad$ Ibid. $\$ 63$

65 Kuptsov and Kuptsova v. Russia (2011), $\$ 100$. As a general rule, a detainee should have a right to participate personally in a hearing where his detention is discussed

66 Bouamar v. Belgium (1988), app. no. 9106/80, $\$ 60$

67 Kuptsov and Kuptsova v. Russia (2011), $\$ 102$

68 Ibid., $\$ 107$

69 Grabowski v. Poland (2015), $\$ 62-63$. See My lawyer, My Rights: European case law regarding the rights of children in conflict with the law - General table (August 2017),

[http://www.mylawyermyrights.eu/Mlmr/european-court-of-human-rights/] Accessed 06.05.2019 


\subsubsection{Article 3}

International documents on human rights set special requirements for the treatment of minors during the pre-trial detention, and the lack of these requirements may in certain circumstances, especially when it has detrimental effect on their health, lead to inhumane and degrading treatment and subsequently to the violation of Article 3 of ECHR. Thus, in Blokhin v Russia, the Court established a violation of Article 3 on account of the lack of necessary medical treatment at the temporary detention centre for juvenile offenders, having regard to his young age (12 years old) and a particularly vulnerable situation, as he was suffering from ADHD. ${ }^{70}$ In Güveç v. Turkey, the Court reached the same conclusion having regard to the applicant's age (15), the length of his detention in prison with adults (four and a half years), the failure of the authorities to provide adequate medical care for his psychological problems, and, finally, the failure to take steps with a view to preventing his repeated attempts to commit suicide. ${ }^{71}$

\section{NEW EU STANDARDS: DIRECTIVE (EU) 2016/800}

Directive (EU) 2016/800 on procedural safeguards for children who are suspects or accused persons in criminal proceedings, adopted as the fifth legislative measure under the EU Roadmap for strengthening procedural rights of suspected or accused persons in criminal proceedings in 2016, provides the minimum rules concerning the procedural rights of children, inter alia, the rights of children deprived of their liberty in criminal proceedings. ${ }^{72}$ In accordance with the Charter of Fundamentals Rights of the European Union, the Directive emphasises the child's best interest as the leading principle in the actions of EUMS.

The Directive sets specific guarantees for children deprived of liberty in line with the existing international standards, however, the added value of the Directive is that upon its adoption these soft law standards became the binding obligations for EUMS. This is especially important in relation to some new safeguards which were not present in earlier binding international texts, such as the right of medical examination. ${ }^{73}$

\footnotetext{
$70 \quad$ Blokhin v. Russia (2016), $\$ 148$

71 Güveçv. Turkey (2009), $\$ 98$

72 For the detailed genesis of the Directive see Cras, S., The Directive on Procedural Safeguards for Children who Are Suspects or Accused Persons in Criminal Proceedings, Genesis and Descriptive Comments Relating to selected Articles, Eucrim Vol. 2, 2016, pp. 109 - 119. Also Rap, S.E.; Zlotnik, D., The Right to Legal and Other Appropriate Assistance for Child Suspects and Accused Reflections on the Directive on Procedural Safeguards for Children who are Suspects or Accused Persons in Criminal Proceedings, European Journal of Crime, Criminal Law and Criminal Justice, Vol. 26, 2018, pp. 115 - 118

73 See Duroy; Foussard; Vanhov, op. cit. note 6, p. 15
} 


\subsection{Limitations to deprivation of liberty and alternatives to detention}

According to Article 10, the deprivation of liberty of a child at any stage of the proceedings may be imposed only as a measure of last resort and limited to the shortest appropriate period of time, taking into account the age and individual situation of the child, and the particular circumstances of the case. ${ }^{74}$

The Directive follows the wording of the UNCRC and the Guidelines on childfriendly justice requiring the "shortest appropriate time", unlike ECHR which, as a stricter standard, requires the shortest possible time. ${ }^{75}$ What amounts to the 'shortest appropriate period of time' and 'the measure of last resort' in a specific case is open to interpretation, which is consistent with the approach taken by ECHR. ${ }^{76}$

In accordance with the ultima ratio nature of detention, the Directive calls for the use of the measures alternative to detention, if appropriate, ${ }^{77}$ such as the prohibition for the child to be in certain places, an obligation for the child to reside in a specific place, restrictions concerning contact with specific persons, reporting obligations to the competent authorities, participation in educational programmes, or, subject to the child's consent, participation in therapeutic or addiction programmes. $^{78}$

Even though the Directive provides for the right to an individual assessment in order to identify the specific needs of children at the earliest appropriate stage of the proceedings (Art. 7), which may be of use, inter alia, for assessing the appropriateness and effectiveness of any precautionary measures, if the child is in the pre-trial detention and his/her waiting for the availability of individual assessment would risk unnecessarily prolonging of such detention, it should be possible to present an indictment in the absence of an individual assessment. ${ }^{79}$

Any detention should be based on a reasoned decision, subject to judicial review by a court. Such a decision should also be subject to periodic review, at reasonable intervals of time, by a court, either ex officio or at the request of the child, the child's lawyer, or a judicial authority which is not the court. These decisions must be taken without undue delay.

Directive 2016/800, Article 10

MIPREDET, op. cit. note 9, p. 15

Fair Trials, op. cit. note 2, note p. 34

Directive 2016/800, Article 11

Directive 2016/800, Recital 46

Ibid., Recital 39 


\subsection{Right to information and right to legal assistance}

As regards the right to information, Directive 2016/800 is a step forward in the right direction as it imposes obligation to EUMS to introduce the child-specific provision for the right to information in criminal proceeding, which is presently not the case. ${ }^{80}$ When children are made aware that they are suspects or accused persons in criminal proceedings, they have to be informed promptly about their rights in accordance with Directive 2012/13/EU on the right to information in criminal proceedings ${ }^{81}$ and about general aspects of the conduct of the proceedings. They must also be informed about the rights set out in this Directive.

Where a child is deprived of liberty, the letter of rights provided to the child pursuant to Directive 2012/13/EU should include clear information on the child's rights under this Directive. ${ }^{82}$ That information has to be provided at the earliest appropriate stage of the proceedings, in respect of the right to limitation of deprivation of liberty and the use of alternative measures, including the right to periodic review of detention, as provided for in Articles 10 and 11, and, upon deprivation of liberty, in respect of the right to specific treatment during such deprivation of liberty, as provided for in Article $12 .{ }^{83}$ Also, children should receive information in respect of the right to a medical examination at the latest upon the deprivation of liberty. ${ }^{84}$

Furthermore, according to Article 5, EUMS have to ensure that the holder of parental responsibility of the child or, where that would be contrary to the best interests of the child, another appropriate adult, is provided with the information that the child receives in accordance with Article 4. In addition, in accordance with the Directive on the access to a lawyer, they have to be informed as soon as possible of the deprivation of liberty and of the reasons pertaining thereto. ${ }^{85}$

80 Radić, I., Right of the child to information according to the Directive 2016/800/EU on procedural safeguards for children who are suspects or accused persons in criminal proceedings, EU and comparative law issues and challenges series, vol 2, 2018, EU law in context - adjustment to membership and challenges of the enlargement, Faculty of Law Osijek, 2018, p. 486

81 Directive 2012/13/EU of the European Parliament and of the Council of 22 May 2012 on the right to information in criminal proceedings [2012] OJ L 142/1

82 Directive 2016/800, Recital 21

83 Ibid., article 4. For detailed analysis of right to information under this Directive see Radić, op. cit. note 80 , pp. $483-386$

84 Directive 2016/800, Recital 20

85 Article 5, Directive 2013/48/EU of the European Parliament and of the Council of 22 October 2013 on the right of access to a lawyer in criminal proceedings and in European arrest warrant proceedings, and on the right to have a third party informed upon deprivation of liberty and to communicate with third persons and with consular authorities while deprived of liberty [2013] OJ L 294/1 
As regards the right to legal assistance, the Directive did not prescribe mandatory legal free of charge assistance during all stages of the criminal procedure, ${ }^{86}$ whereas EUMS may, according to Article 6 (6), derogate from the obligation to provide legal assistance. Yet, regarding children deprived of their liberty, the safety net was installed, ${ }^{87}$ as it requires that children are in any event assisted by a lawyer when they are brought before a competent court or judge in order to decide on detention at any stage of the proceedings within the scope of this Directive and during detention. ${ }^{88}$

\subsection{Right to specific treatment}

Article 12 requires from the EUMS to undertake special measures to ensure adequate treatment of children deprived of liberty, including the requirement of separation of children from adults unless it is considered to be in the child's best interests not to do so, ${ }^{89}$ health care, education and family life. Hence, EUMS have to take appropriate measures to ensure and preserve their health and their physical and mental development; right to education and training, even when these children have physical, sensory or learning disabilities; effective and regular exercise of their right to family life; access to programmes that foster their development and their reintegration into society and respect for their freedom of religion or belief. Children who are deprived of liberty should meet with the holder of parental responsibility as soon as possible, where such a meeting is compatible with the investigative and operational requirements.

Taking into account a particularly vulnerable position of children deprived of liberty, and in order to ensure their personal integrity, the right to a medical examination without undue delay is provided for in Article 8. ${ }^{90}$ Medical examination, with a view to assessing general mental and physical condition, should be as non-invasive as possible and carried out by a physician or another qualified professional, either at the initiative of the competent authorities or in response to a request of the child, the holder of parental responsibility or the child's lawyer.

Finally, it derives that the Directive strengthens the existing standards on deprivation of liberty of children, however the EU legislator have not used the entire potential and the benefits that this Directive could have generated. As some com-

\footnotetext{
86 See Rap, Zlotnik, op. cit. note 72, p. 131

87 Cf. Cras, op. cit. note 72 , p. 114

88 In the light of the temporal scope of the Directive, such detention means pre-trial detention. Ibid., p. 114

89 Children may be detained with young adults, unless this is contrary to the child's best interests

90 Directive 2016/800, Recital 41
} 
mentators stated, it could have homogenised the EU approach to pre-trial detention issues such as the maximum duration of pre-trial detention by implementing a stricter standard in conformity with the international guidelines. ${ }^{91}$

\section{CROATIAN LAW ON PRE-TRIAL DETENTION OF MINORS}

\subsection{Legal grounds}

Pre-trial detention of minors in the Croatian legislation is regulated by the Juvenile Courts Act (JCA) and the Criminal Procedure Act (CPA). ${ }^{92} \mathrm{CPA}$ prescribes two substantive conditions for ordering pre-trial detention: the reasonable suspicion that a person committed an offence and the existence of at least one of five grounds for pre-trial detention, which, together with specific conditions under JCA, must be met for the ordering of this measure to children. ${ }^{93}$ In comparison, not all EUMS impose special criteria for children; in some jurisdictions, the same criteria apply for children and adults. ${ }^{94}$

According to Article 66 of JCA, when conditions for pre-trial detention exist pursuant to CPA, the pre-trial detention shall be ordered against the minor only as a measure of last resort, in proportion to the severity of the offence and the expected sanction, in the shortest necessary duration and only if its purpose cannot be achieved with precautionary measures, measures of temporary accommodation or home detention. ${ }^{95}$ This provision encompasses all the relevant international standards which set up pre-trial detention as a measure of last resort.

In deciding on the pre-trial detention, the judicial authority should be guided by the principle of proportionality, ${ }^{96}$ taking into account all the relevant factors with special diligence, not only the gravity of the offence which is reflected through the height of the prescribed sanction, but also the expected sanction in the specific situation. The latter factor is of the utmost importance and should be assessed

${ }_{91}$ Duroy; Foussard; Vanhov, op. cit. note 6, p. 15.

92 Criminal Procedure Act, Official Gazette 152/2008, 76/2009, 80/2011, 91/2012, 143/2012, 56/2013, $145 / 2013,152 / 2014,70 / 2017$

93 Pre - trial detention may be ordered if there exists reasonable suspicion that a person committed an offence and if there is at least one of five grounds for pre-trial detention described by CPA (causae arresti): danger of flight, danger of collusion, danger of repeating the offence, danger of harassment of the public when the offence was committed under especially grave circumstances, disciplinary pre-trial detention. See, Krapac, op. cit., note 2, p. 389.

94 MIPREDET, op. cit. note 9, p. 6

95 Article 66 (1) JCA

96 On principle of proportionality and pre-trial detention see Đurđević, Z.; Tripalo, D., Trajanje pritvora u svjetlu medunarodnih standarda te domaćeg prava i prakse, Hrvatski ljetopis za kazneno pravo i praksu (Zagreb), Vol. 13, No. 2, 2006, p. $576-578$ 
with special diligence in the proceedings towards junior minors who cannot be subjected to juvenile imprisonment, as only correctional and security measures can be imposed upon them. Notwithstanding the fact that the legislator did not exclude the possibility of ordering pre-trial detention to this category of minors, it should be seen as an exceptional situation and used very restrictively in situations where not only the circumstances of the offence are grave, but, in accordance with the purpose of the proceedings towards minors, where personal and all other circumstances indicate that it would be in the best interest of the child.

\subsection{Formal prerequisites}

Pre-trial detention as the most severe measure for securing the presence of a defendant can be ordered only by a court, whose jurisdiction depends on the stage of the procedure. ${ }^{97}$ During the preliminary and preparatory proceedings, a juvenile judge can order pre-trial detention upon the motion of the state attorney. After the submission of a proposal for the pronouncement of a juvenile sanction, the juvenile panel decides on ordering, prolonging or vacating the pre-trial detention. The panel is required to examine the existence of legal conditions for the further prolongation of pre-trial detention every month until the final decision is taken. Besides the mandatory ex officio control of the soundness of the pre-trial detention, CPA provides judicial control upon the appeal of the parties which may be filed within the term of three days and decided by a juvenile panel of the same or higher-instance court; ${ }^{98}$ and optional control upon a motion of defence for the court to vacate the pre-trial detention. ${ }^{99}$

The judicial authority decides on the pre-trial detention after a non-public hearing to which parties may participate and must be summoned thereto. When the arrested minor is brought before a judge, the judge will question the minor in a form of evidentiary action of questioning and afterwards decide on the pre-trial detention. ${ }^{100}$ The state attorney and the defence counsel must be present during the questioning.

According to the amended CPA, the statement of explanation of decision on the pre-trial detention must specifically and comprehensively indicate the facts and

97 Munivrana Vajda, M.; Ivičević Karas, E., Croatia, in: Verbruggen, F.; Franssen, V., Alphen aan den Rijn (eds.), International Encyclopedia of Laws: Criminal Law, NL: Kluwer Law International, 2016, p. 182

98 Article 67(4) JCA

99 Munivrana Vajda ; Ivičević Karas, op. cit. note 97, p. 183

100 Rittossa, D.; Božićević Grbić, M., Zakon o sudovima za mladež - reformski zahvati i praktične dileme, Hrvatski ljetopis za kazneno pravo i praksu (Zagreb), vol. 19, No. 2, 2012, p. 663 
the evidence supporting reasonable suspicion and reasons for the pre-trial detention, as well as the reasons why the purpose could not be achieved by a less severe precautionary measure and the reasons for justifying further prolongation of the pre-trial detention. These amendments resulted from the ECHR judgements against Croatia where the Court established a violation of Article $5 \$ 3$ due to the insufficiently reasoned decisions of the national courts who had prolonged duration of this measure against the applicants. ${ }^{101}$ This requirement is especially important in the context of the pre-trial detention against minors.

In exercising supervision over the execution of the pre-trial detention, a juvenile judge is required to visit detainees once a week, receive oral and written complaints from them and take appropriate actions in order to remove the irregularities detected. ${ }^{102}$

JCA prescribes special provisions on the duration of pre-trial detention. During the preliminary proceedings, it may last for a maximum of one month, and, for justified reasons, it may be extended for a maximum of one additional month. If a minor is under preparatory proceedings, the pre-trial detention may be prolonged for a further month. In accordance with the ultima ratio requirement, the total duration of the pre-trial detention until the finality of the decision cannot exceed one half of the time prescribed for the duration of the pre-trial detention for adults as per the provisions of Article 133 paragraphs 1, 2, 3 of CPA. Hence, the maximum duration of the pre-trial detention against minors until the decision has become final is twenty-two and a half months for criminal offences subject to legally prescribed long-term imprisonment.

\subsection{Procedural guarantees}

According to JCA, the juvenile judge is obliged to immediately inform the parents, custodian or institution responsible for the minor's education and care, as well as the social welfare centre on the provisional measures, precautionary measures and pre-trial detention in an enclosed institutional facility. ${ }^{103}$ This provision reflects the European standards on the right of a suspected and accused child to have a third person informed of their deprivation of liberty, ${ }^{104}$ however, in accordance with the Directive 2013/48/EU, our legislator should add the possibility of

\footnotetext{
101 E.g. Margaretić v. Croatia (2014), app. no. 16115/13, see Konačni prijedlog Zakona o izmjenama i dopunama Zakona o kaznenom postupku, Zagreb, 2017, p. 73, [edoc.sabor.hr/DocumentView.aspx?entid=2004803] Accessed 06.05.2019

102 Article 66(5) JCA

103 Article 68 (1) JCA-

104 See Art 5(2) of Directive 2013/48/EU
} 
informing another appropriate adult if informing of the holder of parental responsibility would be contrary to the best interests of the child.

The right to information for suspected/accused children in criminal proceeding in Croatia is not regulated by special law (JCA), which means that the general provisions of CPA apply to children. ${ }^{105}$ Regarding the pre-trial detention, that means that a minor will be served the letter of rights together with the decision on pre-trial detention. ${ }^{106} \mathrm{JCA}$ does not contain any provisions on the right to information of specific rights, inter alia, the rights regarding the deprivation of liberty, as prescribed in Directive 2016/800. Consequently, JCA should be amended in order to transpose the provision of the Directive which provides that the child should be informed of the right to the limitation of deprivation of liberty and the use of alternative measures at the earliest appropriate stage in the proceedings, including the right to a periodic review of detention, as well as the right to a medical examination.

The Croatian legislator prescribes mandatory defence for the minors from the first examination and throughout all the stages of the criminal procedure, which also includes the situations concerning the deprivation of liberty. In that way, the Croatian law is harmonised with the European standards and provides even higher guarantees, whereas Directive 800/2016 allows an exception from that right ${ }^{107}$. The communication of the detained minor with his/her lawyer during PTD is, pursuant to CPA and in accordance with Directive 2013/48/EU, confidential and cannot be subjected to any restrictions. ${ }^{108}$

\subsection{Placement in an enclosed institutional facility}

According to Article 66(2), a minor against whom the pre-trial detention has been ordered should be placed in an enclosed institutional facility. The enclosed institutional facility for the placement of a minor must have a diagnostic department and a department for education and work in small groups. During the placement, the minor should be provided with work and education useful for his upbringing and occupation. ${ }^{109}$ By adopting this provision, the conditions for the pedagogi-

\footnotetext{
105 Radić, op. cit., note 80, p. 480

106 Art 239 (2) CPA

107 JCA provides only one exception in situation when state attorney decides in accordance with principle of opportunity. Article 54(2)

108 Art 139 (5) CPA, for comment on coherence of JCA with Directive see Horvat, L., Postupovna jamstva za djecu koja su osumnjičena ili optužena u kaznenim postupcima sukladno Direktivi EU/2016/800, HLJKZP (Zagreb), Vol. 25, No. 2, 2018, pp.596-600

109 Article 66 (3) JCA
} 
cal treatment of juvenile detainees were created, and thus also the possibility to include the time spent in the enclosed institutional facility within the pronounced correctional reformatory measure. ${ }^{110}$ However, this well-conceived idea has yet to be realised, even though it was translated into law in 2011, since enclosed institutional facilities have still not been established, which has seriously brought into question the entire concept of the pre-trial detention focussed on the needs and upbringing of the minors.

In June 2013, the Minister of Justice issued a Decision on the establishment of special detention units for the enforcement of pre-trial detention of minors as a temporary solution until the establishment of special enclosed institutional facilities. ${ }^{111}$ According to the Decision, special detention units for minors have been established in fourteen prisons. In a special detention unit, the minor is separated from adults, but if he/she is placed in the unit alone and such accommodation appears to have a harmful impact on his/her health, the prison director has to immediately inform the competent court for the purpose of procuring its approval for the placement of the minor with an adult who would not be detrimental to him/her. The minors should be allowed to stay in the open space of the prison separately from adults and they should be allowed up to ten visits per month for at least thirty minutes. However, as it follows from the Report of the Ombudsman for children, apart from the administrative decision and the name suggesting the presence of minors, these special detention units are no different from those for adult detainees. ${ }^{112}$ In addition, in 2014 the Committee on the Rights of the Child expressed its concerns regarding the fact that children are subjected to a prolonged pre-trial detention, that they are still detained with adults in some institutions, and that the conditions of detention facilities for children and reformatories are inadequate. ${ }^{113}$

Besides the frequent visits and prolonged stays in the fresh air, other specific requirements of the detention of minors cited by the international documents and JCA have not been systematically provided. Mostly, the minors have not been

110 Article 66 (4) JCA, see Božićević-Grbić, M.; Roksandić Vidlička, S., Reforma maloljetničkog kaznenog prava i sudovanja, HLJKPP (Zagreb), Vol. 18, No. 2, 2011, p. 709. See Article 25 (4) JCA

111 Odluka ministra pravosuđa od 22. svibnja 2013. godine o osnivanju posebnih zatvorskih jedinica u kojima se izvršava istražni zatvor određen maloljetniku, KLASA: 730-02/13-01/45, URBROJ: 51407-01-02-01/5-13/17

112 Izvješće pravobraniteljice za djecu, 2017, Republika Hrvatska Pravobranitelj za djecu, Zagreb, 2018, pp. 96-97,

[http://dijete.hr/izvjesca/izvjesca-o-radu-pravobranitelja-za-djecu/] Accessed 06.05.2019

113 Committee on the Rights of the Child: Concluding observations on the combined third and fourth periodic reports of Croatia, CRC/C/HRV/CO/3-4, 13 October 2014, p. 16

[https://tbinternet.ohchr.org/_layouts/treatybodyexternal/Download.aspx?symbolno=CRC/C/HRV/ CO/3-4\&Lang=En] Accessed 06.05.2019 
provided with work or education, continuous psychosocial support, and other standards that would make the deprivation of liberty less stressful and ensure the minimum conditions appropriate to their age. ${ }^{114}$ These shortcomings were particularly pronounced in the case of the prolonged detention of a fourteen-yearold girl accused for aggravated murder. As the Ombudsman emphasises, despite the self-initiative proactive work of the prison in attempting to secure education and other standards, the absence of systemic solutions has prevented the proper implementation of international documents and the law of the child's rights and interests. ${ }^{115}$

According to the available data, only the prisons in Zagreb and Osijek contain a greater number of juveniles, therefore the Ombudsman recommends the establishment of enclosed institutional facilities in these two cities for the needs of the entire country. ${ }^{116}$ On the other hand, the Government of the Republic of Croatia indicates the need to re-examine the establishment of a separate facility, justifying it with a small number of children in pre-trial detention, ${ }^{117}$ which is a standpoint contrary to all international standards.

\subsection{Case law}

In the case law of the Supreme Court of the Republic of Croatia, it has been confirmed in many instances that, in relation to minors, the provisions on the pretrial detention should be interpreted more restrictively than in relation to adults. Hence, in one decision, the Supreme Court concluded that a continued stay in pre-trial detention (more than three months) would jeopardise the continuation of regular education of the minor accused of drug abuse. ${ }^{118}$ In addition, in the recent case of a fourteen-year-old child accused of an aggravated murder of a 3-yearold child, the Supreme Court abolished the ruling of the first-instance court on the prolongation of pre-trial detention due to the lack of sufficient reasoning on decisive facts regarding the possibility of replacing the pre-trial detention as the most severe coercive measure with less severe precautionary measures. ${ }^{119}$ However, its later decision in the same case was not so argumentative and was consequently abolished by the Constitutional Court of Republic of Croatia.

\footnotetext{
114 Izvješće pravobraniteljice za djecu, op. cit. note 112, pp. 96-97

115 Ibid.

116 Ibid.

117 Izvješće o radu pravobraniteljice za djecu, Republika Hrvatska Pravobranitelj za djecu, Zagreb, 2019, p. 108, [http://dijete.hr/izvjesca/izvjesca-o-radu-pravobranitelja-za-djecu/] Accessed 06.05.2019

118 Supreme Court of Republic of Croatia, II Kž 145/2006-3, 24 February 2006

119 Supreme Court of Republic of Croatia, II Kž 324/17-4, 14 September 2017
} 
The Constitutional Court concluded that the reasons for the prolongation of the pre-trial detention against the applicant, who was detained for more than seven months at the time, were not sufficient nor relevant to the conclusion on the reasonable justification and necessity of application of the pre-trial detention on the basis of the danger of repeating the offence, especially in the context of the adequacy of the conditions of enforcement of this measure in accordance with $\mathrm{Ar}$ ticle 66 paragraphs 2 to 4 of JCA and the application of UNCRC. ${ }^{120}$ Afterwards, upon a new constitutional complaint by the same applicant, the Constitutional Court concluded that the Supreme Court, in accordance with the decision UIII-170/2018, comprehensively assessed the appeals and adequately explained the reasons for the prolongation of the pre-trial detention, i.e. they adequately elaborated the existence of particular circumstances indicating the danger of repeating the same or similar criminal offence and the reasons for the conclusion that the purpose of pre-trial detention in her case cannot be achieved with a more lenient measure. ${ }^{121}$

In this context, we should refer to the conclusion of the Supreme Court according to which the pre-trial detention of a minor essentially does not constitute deprivation of liberty in the conventional sense of that term as it consists of a "special treatment in controlled conditions adjusted to her needs and oriented towards creation of positive basis for future life." ${ }^{122}$ Although all aforementioned factors should indeed be contained in this measure as required by the international standards, we must critically assess this conclusion on a case-specific basis because Croatia has not established a systematic approach to this problem in practice, even though the Decision of Minister of Justice tried to compensate for this shortcoming. In this regard, regrettably the Constitutional Court failed to give a more detailed consideration to the applicant's allegations of inadequate conditions regarding the execution of this measure in relation to the young age of applicant, i.e., to the fact that there was no adequate psychosocial assistance, socio-pedagogical treatment nor education provided. In fact, the lack of these elements can bring into the question the proportionality of the measure in relation to the child's age and the child's best interest.

\section{CONCLUDING REMARKS}

The main principles enshrined within the international and European instruments on children's rights and the ECHR case law can be summarised as follows:

\footnotetext{
120 Paragraphs 8 - 9, Constitutional Court of Republic of Croatia, U-III-170/2018, 18 January 2018

121 Paragraph 9, Constitutional Court of Republic of Croatia, U-III-801/2018, 9 March 2018

122 Supreme Court of Republic of Croatia, II Kž 59/2018-4, 9 February 2018
} 
the pre-trial detention of children should be used only as a measure of last resort, for the shortest appropriate time and where it is strictly necessary to detain them; children should have special treatment, be held separately from adults, and appropriate measures should be taken to ensure and preserve their health, physical and mental development, right to education, training and family life. With adoption of Directive 800/2016, these standards have become binding for EUMS, which guarantees a stronger and more effective protection of children deprived of their liberty across the EU, even though the EU legislator failed to set up somewhat stricter standards in that direction.

The analysed national legislation and case law indicate that the Croatian legislative framework is mostly in line with the European standards, although some amendments should be made in order to completely transpose the EU law. This relates to the right on information of specific rights of children in criminal proceedings, especially regarding the deprivation of liberty.

The major problem as regards the pre-trial detention is the fact that the legislation is not adequately implemented in practice, which makes it futile to a certain extent. JCA prescribes the conditions for the pre-trial detention of a minor deriving from the premise that it will be enforced in enclosed institutional facilities under special conditions that recognise the needs of a minor in accordance with Article 66 paragraphs 2 to 4 . However, these facilities have not been established and, even though there are efforts in the sense that special detention units within prisons for adults have been established, the conditions in which minors are detained are not completely aligned with the international standards and national provisions as they do not recognise or support the specific needs of children. In this regard, the pre-trial detention of junior minors (14-16 years old) who cannot be subjected to juvenile imprisonment after the trial is perceived as particularly problematic.

However, it should be noted that the pre-trial detention of children of that age is allowed not only in Croatian law, but in the law of all EU Member States. Furthermore, ECHR does not deny the possibility of ordering the pre-trial detention to children of young age, i.e., it does not consider it a violation of the right to liberty per se, nor does the Directive set the age limit in that direction. However, it is of vital importance to adapt the content of this measure to the young age of perpetrators and use it in exceptional cases.

Whereas the time spent in an enclosed institutional facility during the criminal proceedings should be included in the pronounced correctional reformatory measures, these two measures, though different by their legal purpose and nature, should be essentially similar in content, i.e., they should both provide adequate 
conditions for children. If the national law is unable to ensure these conditions in relation to the pre-trial detention, a more intrusive measure of coercion is imposed on junior minors during the trial than after the trial, which is unacceptable. This has been a well-recognised problem for a while, and instead of resorting to partial and provisional solutions, it is necessary to take a systematic approach which will primarily take into account the child's best interest.

\section{REFERENCES}

\section{BOOKS AND ARTICLES}

1. Božićević-Grbić, M.; Roksandić Vidlička, S., Reforma maloljetničkog kaznenog prava i sudovanja, HLJKPP (Zagreb), Vol. 18, No. 2,2011, pp. 679-715

2. Cras, S., The Directive on Procedural Safeguards for Children who Are Suspects or Accused Persons in Criminal Proceedings, Genesis and Descriptive Comments Relating to selected Articles, Eucrim, Vol. 2, 2016, pp. 109 - 120

3. Đurdević, Z.; Tripalo, D., Trajanje pritvora u svjetlu mectunarodnih standarda te domaćeg prava i prakse, Hrvatski ljetopis za kazneno pravo i praksu (Zagreb), Vol. 13, No. 2, 2006, pp. 551-596

4. Graovac, G., Zaštita prava na osobnu slobodu u praksi Ustavnog suda Republike Hrvatske, doktorski rad, Zagreb, 2017

5. Harris, D.J.; O’Boyle, M.; Bates, E.P.; Buckley, M., Harris, O'Boyle \& Warbrick, Law of the European Convention on Human Rights, Oxford University Press, 2014

6. Horvat, L., Postupovna jamstvaza djecu koja su osumnjičena ili optužena u kaznenim postupcima sukladno Direktivi EU/2016/800, HLJKZP (Zagreb), Vol. 25, No. 2,2018, pp. 575 - 603

7. Krapac, D. et al., Kazneno procesno pravo, Prva knjiga: Institucije, Zagreb, 2014

8. Liefaard, T., Deprivation of Liberty of Children in: Kilkelly, U.; Liefaard, T. (eds.), International Human Rights of Children, Springer, 2019, pp. 321 - 257

9. Manco, E., Detention of the Child in the Light of International Law-A Commentary on Article 37 of the United Nation Convention on the Rights of the Child, Amsterdam Law Forum, Vol. 7, No. 1, 2015, pp. $55-75$

10. Munivrana Vajda, M.; Ivičević Karas, E., Croatia, in: Verbruggen, F.; Franssen, V., Alphen aan den Rijn (eds.), International Encyclopedia of Laws: Criminal Law, NL: Kluwer Law International, 2016

11. Radić, I., Right of the child to information according to the Directive 2016/800/EU on procedural safeguards for children who are suspects or accused persons in criminal proceedings, EU and comparative law issues and challenges series, Vol 2, 2018, EU law in context - adjustment to membership and challenges of the enlargement, Faculty of Law Osijek, 2018., pp. 468 $-491$

12. Rap, S.E.; Zlotnik, D., The Right to Legal and Other Appropriate Assistance for Child Suspects and Accused Reflections on the Directive on Procedural Safeguards for Children who are Suspects or Accused Persons in Criminal Proceedings, European Journal of Crime, Criminal Law and Criminal Justice, Vol. 26, 2018, pp. $110-131$ 
13. Rittossa, D.; Božićević Grbić, M., Zakon o sudovima za mladež-reformski zahvati i praktične dileme, Hrvatski ljetopis za kazneno pravo i praksu (Zagreb), Vol. 19, No. 2, 2012, pp. 615667

14. Trechsel, S., Human Rights in Criminal Proceedings, Oxford, 2006

\section{INTERNATIONAL DOCUMENTS}

1. Convention for the Protection of Human Rights and Fundamental Freedoms, Council of Europe, 1950

2. Guidelines of the Committee of Ministers of the Council of Europe on child-friendly justice adopted by the Committee of Ministers of the Council of Europe on 17 November 2010.

3. Recommendation CM/Rec (2008) 11 of the Committee of Ministers to member states on the European rules for juvenile offenders subject to sanctions or measures adopted by the Committee of Ministers on 5 November 2008

4. Recommendation of the Committee of Ministers to Member States of the Council of Europe on social reactions to juvenile delinquency (no. R (87)20)

5. Recommendation Rec (2003) 20 of the Committee of Ministers of the Council of Europe concerning new ways of dealing with juvenile delinquency and the role of juvenile justice

6. UN Convention on Rights of a Child, General Assembly resolution 44/25 of 20 November 1989

7. United Nations Rules for the Protection of Juveniles Deprived of their Liberty, Adopted by General Assembly resolution 45/113 of 14 December 1990

8. United Nations Rules for the Protection of Juveniles Deprived of their Liberty, Adopted by General Assembly resolution 45/113 of 14 December 1990

\section{EU LAW}

1. Directive (EU) $2016 / 800$ on procedural safeguards for children who are suspects or accused persons in criminal proceedings [2016] OJ L 132

2. Directive 2012/13/EU of the European Parliament and of the Council of 22 May 2012 on the right to information in criminal proceedings [2012] OJ L 142/1

3. Directive 2013/48/EU of the European Parliament and of the Council of 22 October 2013 on the right of access to a lawyer in criminal proceedings and in European arrest warrant proceedings, and on the right to have a third party informed upon deprivation of liberty and to communicate with third persons and with consular authorities while deprived of liberty [2013] OJ L 294/1

\section{ECHR case law}

1. Agit Demir v. Turkey (2018), app. no. 36475/10

2. Blokhin v. Russia (2016), app. no. 47152/06

3. Bouamar v. Belgium (1988), app. no. 9106/80

4. Dinç and Çakir v. Turkey (2013), app. no. 66066/09 
5. Grabowski v. Poland (2015), app. no. 57722/12

6. Ichin and Others $v$. Ukraine (2010), app. nos. 28189/04 and 28192/04,

7. J.D. v. Danmark (2012), app. no. 34421/09

8. Korneykova v. Ukraine (2012), app. no. 39884/05

9. Kuptsov and Kuptsova v. Russia (2011), app. no. 6110/03

10. Margaretić v. Croatia (2014), app. no. $16115 / 13$

11. Nart v. Turkey (2008), app. no. 20817/04

12. Selçuk v. Turkey (2006), app. no. 21768/02

13. X. v. Switzerland, no. 8500/79, Commission decision of 14 December 1979

14. Zherdev v. Ukraine (2017), app. no. 34015/07

\section{LIST OF NATIONAL REGULATIONS, ACTS AND COURT DECISIONS}

1. Constitutional Court of Republic of Croatia, U-III-170/2018, 18 January 2018

2. Constitutional Court of Republic of Croatia, U-III-801/2018, 9 March 2018

3. Criminal Procedure Act, Official Gazette 152/2008, 76/2009, 80/2011, 91/2012, 143/2012, 56/2013, 145/2013, 152/2014, 70/2017

4. Juvenile Courts Act, Official Gazette, 84/11, 143/12, 148/13, 56/15

5. Odluka ministra pravosuđa od 22. svibnja 2013. godine o osnivanju posebnih zatvorskih jedinica u kojima se izvršava istražni zatvor određen maloljetniku, KLASA: 730-02/13-01/45, URBROJ: 514-07-01-02-01/5-13/17

6. Supreme Court of Republic of Croatia, II Kž 145/2006-3, 24 February 2006

7. Supreme Court of Republic of Croatia, II Kž 324/17-4, 14 September 2017

8. Supreme Court of Republic of Croatia, II Kž 59/2018-4, 9 February 2018

\section{WEB REFERENCES}

1. Comments on Draft General Comment No. 24 (201x), replacing General Comment 10 (2007) on Children's rights in juvenile justice, Department of Child Law, Leiden Law School, Leiden University, The Netherlands Leiden, 7 January 2019, [https://www.universiteitleiden.nl/binaries/content/assets/rechtsgeleerdheid/instituut-voor-privaatrecht/jeugdrecht/leiden-university-comments-draft-gc-no.-24-final.pdf] Accessed 04.05.2019

2. Committee on the Rights of the Child, Draft General Comment No. 24 (201x), replacing General Comment 10 (2007) on Children's rights in juvenile justice, [https://www.ohchr. org/EN/HRBodies/CRC/Pages/DraftGC10.aspx] Accessed 04.05.2019

3. Committee on The Rights of the Child, General Comment No. 10 (2007) Children's rights in juvenile justice, CRC/C/GC/10 25 April 2007, [https://www.refworld.org/ docid/4670fca12.html] Accessed 06.05.2019

4. Committee on the Rights of the Child: Concluding observations on the combined third and fourth periodic reports of Croatia, CRC/C/HRV/CO/3-4, 13 October 2014, [https://tbinternet.ohchr.org/_layouts/treatybodyexternal/Download.aspx?symbolno=CRC/C/HRV/ CO/3-4\&Lang=En] Accessed 06.05.2019 
5. Duroy, S.; Foussard, C.; Vanhove, A., Pre-trial detention of children in the EU, Analysis of legislations and practices in EU28,

[http://www.ijjo.org/sites/default/files/mipredet_ijjo2015_updated07122016.pdf] Accessed 03.05.2019

6. European Union Agency for Fundamental Rights: Mapping minimum age requirements with respect to the rights of the child in the EU, 2017, [https://fra.europa.eu/en/ publications-and-resources/data-and-maps/minag?mdq1=theme\&mdq2=3509] Accessed 04.05.2019

7. Fair Trials: Advancing the Defence Rights of Children Manual for Practitioners, October 2018, [https://www.fairtrials.org/publication/advancing-defence-rights-children] Accessed 06.05.2019

8. Guide on Article 5 of the Convention - Right to liberty and security, Council of Europe/European Court of Human Rights, 2019, [https:/www.echr.coe.int/documents/guide_art_5_ eng.pdf] Accessed 06.05.2019

9. Izvješće o radu pravobraniteljice za djecu, Republika Hrvatska Pravobranitelj za djecu, Zagreb, 2019, [http://dijete.hr/izvjesca/izvjesca-o-radu-pravobranitelja-za-djecu/] Accessed 06.05.2019

10. Izvješće pravobraniteljice za djecu, 2017, Republika Hrvatska Pravobranitelj za djecu, Zagreb, 2018, [http://dijete.hr/izvjesca/izvjesca-o-radu-pravobranitelja-za-djecu/] Accessed 06.05.2019

11. Konačni prijedlog Zakona o izmjenama i dopunama Zakona o kaznenom postupku, Zagreb, 2017, [edoc.sabor.hr/DocumentView.aspx?entid=2004803] Accessed 06.05.2019

12. MIPREDET: Analysis of procedures and conditions of minors' pre-trial detention, JUST/2014/JACC/AG/PROC/6600, Final report,

[https://www.oijj.org/sites/default/files/mipredet._final_publication.pdf] Accessed 04.05.2019

13. My lawyer, My Rights: European case law regarding the rights of children in conflict with the law - General table (August 2017),

[http://www.mylawyermyrights.eu/Mlmr/european-court-of-human-rights/] Accessed 06.05.2019

14. Statistical Yearbooks of the Republic of Croatia, Croatian Bureau of Statistics, available at [https://www.dzs.hr/default.htm] Accessed 06.05.2019

15. Van den Brink, Y., Pre-Trial Detention of Children, Children's Rights, Welfarism and Control, World Congress on Justice for Children, 29 May 2018, [https://j4c2018.org/wp-content/ uploads/2018/04/YANNICK-VAN-DEN-BRINK-PRESENTATION-PRETRIAL-DETENTION-29.05.18-ROOM-III.pdf] Accessed 03.05.2019

16. Volz, A., Stop the violence! The overuse of pre-trial detention, or the need to reform juvenile justice systems, Review of Evidence, Defence for Children International, Geneva, July 2010, [https://defenceforchildren.org/wp-content/uploads/2010/04/PretrialDetentionReportdci.pdf] Accessed 03.05.2019 